\title{
Obnova zagrebačkog Donjeg grada nakon potresa iz perspektive stanara
}

\author{
Anđelina Svirčić Gotovac \\ Institut za društvena istraživanja u Zagrebu, Hrvatska \\ e-mail:svircic@idi.hr
}

\author{
Jelena Zlatar Gamberožić \\ Institut za društvena istraživanja u Zagrebu, Hrvatska \\ e-mail: jelena@idi.hr
}

\author{
Mirjana Adamović \\ Institut za društvena istraživanja u Zagrebu, Hrvatska \\ e-mail:mirjana@idi.hr
}

SAŽETAK Nakon zagrebačkog i petrinjskog potresa postalo je jasno kako je postpotresna gradnja i obnova stanova i zgrada ključna tema u zagrebačkom i prostoru središnje Hrvatske. U procesu planiranja postpotresne sanacije i obnove, među ostalim, ističe se uključenost stanovnika kao jedan od ključnih faktora njegove uspješnosti. Tom je namjerom vođeno i ovo istraživanje, koje je provedeno kvalitativnom metodom polustrukturiranih intervjua na uzorku vlasnika stanova i predstavnika suvlasnika u zagrebačkom Donjem gradu $(\mathrm{N}=27)$. U radu se iznose mišljenja sugovornika o vrsti oštećenja te problemima s kojima su se susreli vezano uz učinkovitost rada gradskih i državnih institucija. Istraživanje nadalje ukazuje na probleme na razini funkcioniranja samih zgrada, koji uključuju nedostatnu visinu zajedničke pričuve te (ne)zadovoljstvo radom predstavnika suvlasnika i upravitelja zgrada. Rezultati pokazuju kako sanacija zgrada teče sporo te da proces obnove nije u skladu s očekivanjima sugovornika, odnosno da će se u procesu obnove stanari, unatoč subvencijama i donesenom Zakonu o obnovi te mogućnostima sufinanciranja, trebati značajnije osloniti na vlastite financije. Po pitanju cjelovite obnove gradskog središta nakon potresa, stanovnici smatraju kako je obnovu središta grada potrebno planirati u smjeru zadržavanja postojećeg identiteta grada te uravnoteženog razvoja između staroga i novoga te stambenog i poslovnog izgleda grada. Očekuju također i obnovu koja će pridonijeti održivijem urbanom životu u središtu grada koji pridaje sve veću važnost potrebama građana i podizanju njihove kvalitete života kako ne bi došlo do sve radikalnijih procesa turistifikacije i apartmanizacije, odnosno procesa iseljavanja iz središta.

Ključne riječi: urbana obnova, postpotresna obnova, središte grada, intervjui, Zagreb.

Copyright (C) 2021 Institut za društvena istraživanja u Zagrebu - Institute for Social Research in Zagreb Sva prava pridržana - All rights reserved 


\section{Uvod}

U posljednja tri desetljeća tranzicije iz socijalizma prema tržišnom kapitalizmu u području urbanog i prostornog planiranja sve je vidljivije slabljenje uloge države u procesima urbane obnove i revitalizacije, posebno urbanističkih cjelina kao što su stare gradske jezgre i blokovi izgrađeni s kraja 19. st. i nakon 2. svjetskog rata. U postsocijalističkom kontekstu dominantni su tržišno orijentirana ekonomija i neoliberalno razmišljanje, a država ima malo političkog utjecaja u urbanom planiranju i novoj legislativi (Tosics, 2005.; Hirt, 2012.). Transformacija prostora, posebno glavnih gradova, ključno je obilježje kojim se može pojasniti promjene nastale u središtima i periferijama postsocijalističkih gradova. Potaknute su tržišnom vrijednošću prostora, gdje su središnji dijelovi gradova postali dodatno atraktivni u uvjetima tržišne ekonomije i procesa privatizacije. U kontekstu izražene komercijalizacije prostora postsocijalističkih gradova, među njima i Zagreba (Čaldarović, 2008.; Svirčić Gotovac i Zlatar Gamberožić, 2020.), mora se promatrati i sam proces urbane obnove. U tom je kontekstu izrazito važno temeljito i sustavno planirati specifično gradsko područje središta grada, koje je vrlo osjetljivo na brojne ekonomske, ali i demografske te socijalne promjene. Stoga će se ovaj rad baviti obnovom nakon potresa i njegovim posljedicama, kao i cjelovitom urbanom obnovom Donjeg grada, onako kako je stanovnici vide.

Potres je (slike 1 i 2) uz Zagreb pogodio i dijelove Krapinsko-zagorske te Zagrebačke županije, a bio je jačine 5,5 stupnjeva po Richteru. Dogodio se 22. ožujka 2020. godine u 6:24 sati, s epicentrom sedam kilometara sjeverno od središta Zagreba (Markuševec) na dubini od deset kilometara. Prema podacima Ministarstva prostornoga uređenja, graditeljstva i državne imovine u potresu je oštećeno 25 tisuća zgrada, što privatnih, što javne namjene. Nakon potresa neuporabljivo je ili privremeno neuporabljivo više od šest tisuća zgrada, među kojima su dječji vrtići, osnovne škole, srednje škole, fakulteti, instituti, znanstvene ustanove i ustanove kulture. Oko 1,5 posto oštećenih zgrada javne je namjene, a 98,5 posto zgrade su u privatnom vlasništvu. ${ }^{1}$

1 Osim navedenih oštećenja razorena je i iznimno vrijedna visoko urbana struktura glavnog grada Republike Hrvatske, gdje se procjenjuje da su najveća oštećenja u gradskim četvrtima Donji grad, Gornji grad - Medveščak, Gornja Dubrava, Maksimir, Podsljeme i Sesvete (Izvor: https://mgipu.gov.hr) (25. travnja 2021.) 
Slike 1. i 2.

Zagreb nakon potresa 22. 3. 2020.

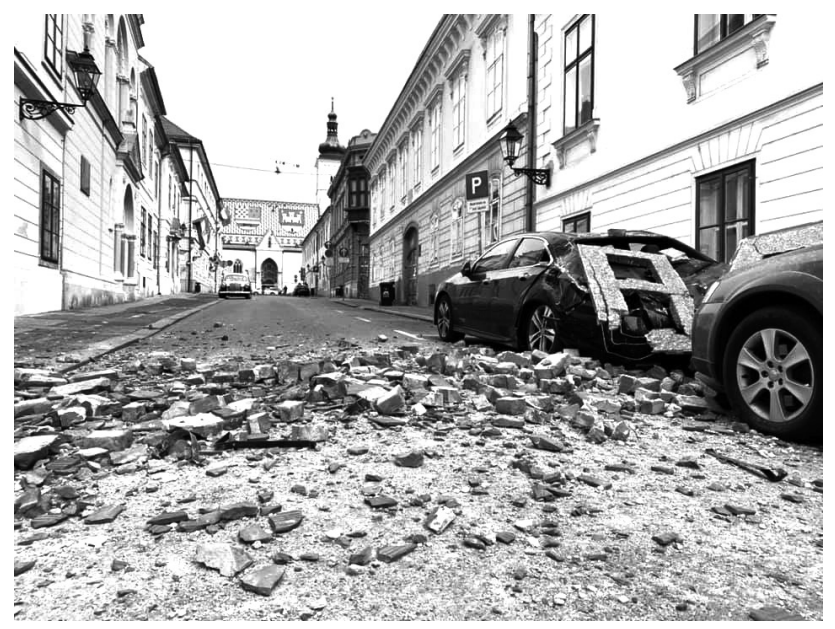

Izvor: https://www.startnews.hr/news/50-foto-zagreb-nakon-potresa-slike-uzasa-sredista-grada-ljudi-ustrahu-katedrala-bez-jednog-tornja/ (17. travnja 2021.)

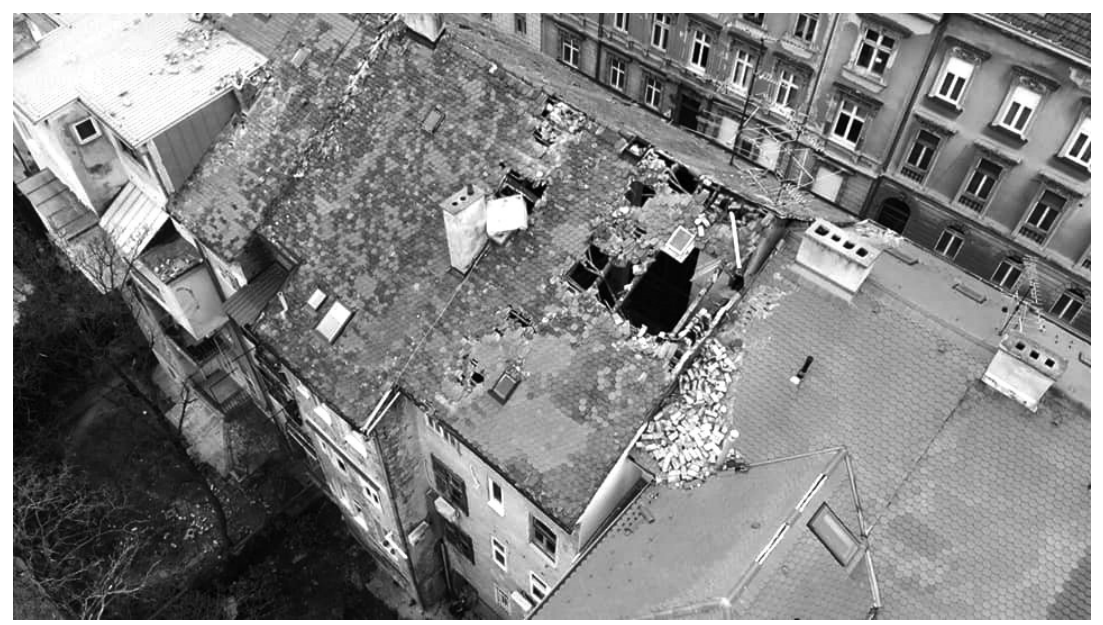

Izvor: https://www.dblog.hr/price/ne-smijemo-dozvoliti-da-obnova-traje-11-godina-kao-u-italiji// (17. travnja 2021.)

Središte je grada ponajviše stradalo u potresu, a prema stručnjacima takva je situacija bila i pri posljednjem većem potresu iz 1880. godine. S obzirom na stanje i prije svega starost, ali i zapuštenost zgrada odnosno stambenog fonda, posebno su stradali Donji i Gornji grad. Brojne građevine nisu bile značajnije obnavljane od vremena kad su građene, a također su pretrpjele brojne (ne)dozvoljene dogradnje, koje su dodatno pogoršale situaciju i uzrokovale (još) veća oštećenja (Damjanović, 2020.). Nakon prvog potresa iz ožujka 2020. dogodio se još razorniji potres magnitude 6,2 prema Richteru 
krajem 2020. godine, 29. prosinca. Pogodio je Sisačko-moslavačku županiju, epicentar mu je bio tri km jugozapadno od grada Petrinje. U zagrebačkom potresu poginula je jedna osoba, a u petrinjskom njih sedam, dok je više desetaka osoba ozlijeđeno. Petrinjski je potres postao jedan od dvaju najjačih instrumentalno zabilježenih potresa u Republici Hrvatskoj (od 1909. godine) ${ }^{2}$, a njegovo razorno djelovanje osjetilo se i u Zagrebu, gdje je došlo do dodatnih šteta posebno u središnjim dijelovima grada na najstarijim objektima. Unio je još veću neizvjesnost i nesigurnost među građane i u krajnji ishod sanacije njihovih stanova i zgrada te obnove središta Zagreba. Gradska središta i povijesne jezgre dijelovi su grada izrazito osjetljivi na procese transformacije i urbane obnove, a pogotovo nakon razornih potresa. Stanarima podsljemenskih naselja, koja su zabilježena kao epicentar potresa, za prvu pomoć dodijeljene su privremene smještajne jedinice u obliku kontejnera pored njihovih oštećenih kuća. Za jedan dio stanara iz središta Zagreba koji nisu mogli biti ni kod rodbine ni u nekom svom alternativnom smještaju pronađeno je rješenje smještanja u studentski dom Cvjetno naselje, u kojem su proveli gotovo šest mjeseci, a zatim su premješteni na novu lokaciju hostela Arena u Remetincu, gdje su neki ostali i do danas (60-ak osoba). Prvotno ih je bilo nekoliko stotina te se dio njih vratio kućama ili su uzeli stanove u najam. ${ }^{3}$ Sve te hitne intervencije donijele su kratkotrajnu sigurnost građanima, ali je većim dijelom, kako su izvještavali i mediji, bilo prisutno nezadovoljstvo učinjenim i neizvjesnost $s$ obzirom na buduće poteze vlasti. Država je nakon te prve faze stanovnicima u sljedećim mjesecima osigurala i najam ${ }^{4}$ zamjenskih stanova kako bi oni koji su ostali bez krova nad glavom bili adekvatnije smješteni.

Stoga je u ovome radu u fokusu mišljenje stanovnika središta Zagreba, Donjega grada, o mogućnostima obnove od potresa jer su njihovi stanovi i zgrade udaljeni svega nekoliko kilometara od epicentra i pretrpjeli su znatne štete. U kvalitativnom istraživanju, čije rezultate u radu prezentiramo, nastojali smo ispitati o kakvoj je vrsti šteta riječ te što stanovnici Donjega grada očekuju od obnove prema nekoliko aspekata. S obzirom na nužnost urbane obnove tog dijela grada zanimalo nas je i kako stanovnici Donjega grada vide urbanu i protupotresnu obnovu.

2 Potres se osjetio diljem Hrvatske i u okolnim zemljama, a intenzitet u epicentru preliminarno je ocijenjen na VIII - IX stupnjeva EMS ljestvice. Dan ranije, 28. prosinca 2020. u 6 sati i 28 minute dogodio se jak potres magnitude $\mathrm{M}=5,0 \mathrm{~s}$ epicentrom kod Petrinje. Isti dan uslijedilo je još nekoliko jačih potresa. Izvor: https://www.pmf.unizg.hr/geof/seizmoloska sluzba/potresi kod petrinje (15. travnja 2021.)

3 Istraživanja o prirodnim katastrofama i nepogodama u SAD-u pokazuju da većina oštećenika ostaje $s$ prijateljima ili obiteljima, dok samo manji broj ostaje u hotelima ili motelima. Najmanji dio ostaje u skloništima, 5 - 15\%, ovisno o vremenskim uvjetima i financijskim mogućnostima oštećenih i izbjeglih (Lindell, 2013.:809).

${ }^{4}$ Vlada je 27. kolovoza 2020. godine usvojila i Zaključak o privremenom stambenom zbrinjavanju osoba čije su nekretnine stradale u potresu na području Grada Zagreba, Krapinsko-zagorske županije i Zagrebačke županije, privremeno smještenih u Studentskom domu Cvjetno naselje. Sredstva za tu namjenu osigurat će se iz Fonda solidarnosti EU-a (https://mgipu.gov.hr/o-ministarstvu-15/djelokrug/graditeljstvo-98/obnova-zgrada-ostecenih-potresom-na-podrucju-grada-zagreba-i-okolice/10668) (24. travnja 2021.). 


\section{Urbana obnova na primjeru Zagreba}

Urbana obnova (engl. urban renewal), revitalizacija, regeneracija i rekonstrukcija vrlo se slično definiraju jer općenito za cilj imaju uređenje zapuštenih i ostarjelih prostora gradova. Svi pojmovi uglavnom imaju drukčiji prizvuk, tumačenje i specifičnosti sagledavaju li ih različite struke kao što su urbanisti, arhitekti, sociolozi ili ekonomisti (Jukić, Mrđa i Perkov, 2020.). Razlika je ponajviše u tome koliko će gradskog prostora i koje socijalne slojeve urbana obnova obuhvatiti, a najčěscé se odnose na uređenje i revitalizaciju centralnih dijelova (trgova, ulica i blokova), ali i zgrada od posebne kulturne vrijednosti. Proces urbane obnove u europskim gradovima od šezdesetih i sedamdesetih godina 20. st. bio je povezan s pomodnim pokretom očuvanja i rekonstrukcije povijesnog nasljeđa (Čaldarović, 1989.:123), čime se nastojalo gradovima vratiti prijašnji izgled naglašavajući pritom njihove povijesne vrijednosti. Ti su centralni prostori ujedno i najatraktivniji javni prostori gradova. Građani su vezani uz taj prostor na specifičan način budući da on prezentira povijesne i kulturne vrijednosti grada te se tako pokazuje i njegov identitet. Na taj odnos utječu ponajviše akteri koji provode urbanu politiku i donose odluke o obnovi i revitalizaciji tih specifičnih gradskih prostora.

Urbana je obnova sastavni dio urbane politike jednog grada te ovisi o modelima suradnje s različitim akterima, ali i sredstvima koje politika u nju ulaže, pa je i vrlo kompleksna. Pristup urbanoj preobrazbi sveobuhvatan je, od temeljne infrastrukturno-oblikovne obnove, preko rješavanja društveno-ekonomskih pitanja, sve do brige za zaštitu okoliša i stvaranje održivih urbanih procesa (Jukić, Mrđa i Perkov, 2020.:20). Programima urbane obnove tako se nastoji podići kvaliteta života i stanovanja, infrastrukturna opremljenost susjedstva te dovesti ili osnažiti rekreacijske, kulturne i socijalne sadržaje. Obnova grada neprekinut je proces njegova uređenja, nije samo sanacija već je i unapređenje i povećanje ukupne vrijednosti izgrađenoga prostora (Pegan i Jukić, 2001.:142).

Svi ti programi i modeli često se ostvaruju samo djelomično, pogotovo na primjerima gradova u tranziciji ili postsocijalističkih gradova kao što je Zagreb. U njemu su se već od 1990-ih, a naročito od 2000-ih, događale izrazito velike promjene najvažnijih gradskih lokacija, koje često nisu imale za krajnji cilj procese sustavne revitalizacije i obnove, već samo parcijalnu i često privatnu intervenciju u određeni prostor. Primjeri transformacija grada Zagreba koji se smatraju obnovom („obnova“ trgova, visoka poslovna izgradnja, trgovački centri, podzemne garaže itd.) napravljeni su isključivo prema interesima investitora i nose sa sobom razne negativne posljedice: opterećenje infrastrukture i neprofitabilnost za grad, stvaranje prometnih gužvi, promjenu vizure i identiteta grada, smanjenje broja trgovina u gradskom centru, stvaranje novih potencijalnih brownfieldsa, stihijsku izgradnju, loše pozicioniranje novih elemenata i građevina (Zlatar, 2013.). Time, na temelju procesa komercijalizacije prostora (Hegedüs i Tosics, 1998.; Svirčić Gotovac i Zlatar Gamberožić, 2020.), na atraktivnijim 
gradskim lokacijama dolazi do uglavnom financijskog ulaganja u gradnju i obnovu, ali i odlučivanja o budućem izgledu i identitetu postsocijalističkih gradova. U takvom je kontekstu proces urbane obnove otežan i najčešće parcijalan. Dosadašnja su sociološka istraživanja u nas (Seferagić, 2013.; Šarinić i Čaldarović, 2015.; Svirčić Gotovac, 2010.) pokazala kako velik dio planirane obnove nije ostvaren i da je sustavna urbana obnova ustupila mjesto kratkoročno planiranim gradskim projektima. Utjecaj takvih intervencija i „obnove“ ne samo na fizičku i socijalnu infrastrukturu grada već i na njegovu vizuru i identitet je negativan. U takvoj je situaciji urbana obnova kao socijalna i fizička revitalizacija grada u smislu podizanja kvalitete života građana te kao obnova kulturno-povijesne baštine ostala neispunjena do danas.

Već su početkom 1990-ih neki autori kao Rogić (1991.) upozoravali kako praksu obnove starih jezgara kod nas uopće ne možemo zvati revitalizacijom ili urbanom obnovom u punom smislu riječi, te je imenuju zamjenskim tipovima: (1) radikalnom cityzacijom, (2) elitizacijom, (3) zgušnjavanjem funkcionalnog konteksta i (4) oronulom svakodnevnicom. Prvi tip označava revitalizaciju u smislu reduciranja gradske jezgre na skup scenografskih elemenata, jer novi „korisnik“ jezgre nije više odrediv na individualnoj razini, u liku stalnog stanovnika, već je sveden na subjekte tercijarnog sektora: hotele, banke, trgovine. Drugi tip označava one pokušaje obnove koji se oslanjaju na bogatije slojeve stanovnika. Obnova se u tom smislu odvija kao skup postupaka kojima se operacionaliziraju interesi investicijski najsposobnijih slojeva i pojedinaca. Takav primjer prisutan je u obnovi Gornjega i Donjeg grada u Zagrebu. Treći tip označava koncentraciju djelatnosti, tj. pluralizaciju ekonomskih aktivnosti i poslova, a život u staroj jezgri dopušten je tek toliko koliko je potrebno da bi se promovirao rad. Četvrti tip nije planska opcija, već je posljedica nepriznavanja posebne uloge stare jezgre u reprodukciji i obnovi grada, pa se zapravo radi o odsutnosti planskih intervencija (Rogić, 1991.:38-43). Međutim, obnova središta grada potrebna je da ne bi došlo do potpune zapuštenosti grada ili odsutnosti obnove kulturno-povijesnog naslijeđa, ali i zbog stabilnosti sociodemografske strukture stanovništva u smislu njegove mješovitosti ili heterogenosti.

Često se iz intencije uređenja i rekonstrukcije specifičnih gradskih područja proces urbane obnove transformira u proces gentrifikacije ili elitiziranja pojedinog dijela grada, što ostavlja uglavnom ekonomske posljedice vidljive u gradnji šoping-centara (primjer šoping-centra Cvjetni na Cvjetnom trgu) (Svirčić Gotovac, 2010.). Nekoliko godina unazad taj proces poprima i oblik turistifikacije i apartmanizacije, kada stanovnici zbog iznajmljivanja svojih nekadašnjih stanova i njihovog pretvaranja $u$ apartmane sele izvan središta grada. Time se ekonomski profit stavlja iznad funkcije stanovanja, čime nepovratno dolazi do trajnog iseljavanja i napuštanja jezgre. U cilju očuvanja najvećih vrijednosti grada i gradskog središta komercijalizacija kojom se prostor promatra kao objekt ostvarivanja dodatnog profita trebala bi biti zamijenjena dugoročno održivim programima obnove, otpornima na globalizacijske i komercijali- 
zacijske utjecaje. U kontekstu razvoja prostora gradova model obnove gradskih središta posebno je važna tema nakon određenih elementarnih nepogoda, a u zagrebačkom slučaju potresa iz ožujka i prosinca 2020. godine.

\section{Postpotresna obnova u Zagrebu}

Otkad su problematika potresa i postpotresne obnove postali dio zagrebačke svakodnevice, mogući modeli sanacije i obnove oštećenih kuća, stanova i zgrada stalna su tema stručnog i političkog javnog diskursa. Uza sve probleme nastale nakon potresa, važno je istaknuti da se potres dogodio u situaciji globalne pandemije bolesti COVID-19, zbog koje su procesi obnove i sanacije bili dodatno otežani. Nakon prvih mjeseci od potresa nastupilo je i vrijeme pripreme za parlamentarne izbore u srpnju 2020. godine, što je također potres stavilo u drugi plan. U hrvatskom se političkom diskursu ostavljao dojam izrazite zainteresiranosti za što bržu obnovu, iako je novi Zakon o obnovi donesen tek u rujnu 2020., pola godine od potresa. Obnovom koju se naziva i konstrukcijskom obnovom ${ }^{5}$ osigurava se financijski okvir obnove, mogućnost postpotresnog ojačavanja zgrada i kuća te stambeno zbrinjavanje stanovnika pogođenih potresom. Nakon toga, u studenom 2020. godine, osnovan je Fond za obnovu Grada Zagreba, Krapinsko-zagorske i Zagrebačke županije, u kojem sudjeluju državne i gradske institucije zajedno, te je donesen i prvi Program mjera. ${ }^{6}$ Mjere su usmjerene prema stanovnicima koji su egzistencijalno ugroženi zbog gubitka stambene sigurnosti ili su pak u vrlo nepovoljnoj materijalnoj situaciji zbog novonastalih troškova koje će sanacija iziskivati. U obnovi se gradskog središta osim urbanističkih, ekonomskih i tehničkih te kulturno-povijesnih aspekata obnove dodatno mora razmišljati i o demografskim problemima depopulacije i iseljavanja, koje i inače obilježavaju zagrebačku jezgru, kako bi se zadržalo stanovnike i podigla njihova kvaliteta života. ${ }^{7}$

5 Zakon o obnovi zgrada oštećenih potresom u Zagrebu, Krapinsko-zagorskoj i Zagrebačkoj županiji donio je Hrvatski sabor 11. rujna 2020. godine. Njime se uređuje način i postupak obnove odnosno uklanjanja zgrada oštećenih potresom 22. ožujka 2020., određuje se gradnja zamjenskih obiteljskih kuća i stambeno zbrinjavanje osoba pogođenih tom katastrofom, nadležna tijela kao i rokovi za postupanje te modeli financiranja (https://mgipu.gov.hr/o-ministarstvu-15/djelokrug/graditeljstvo-98/obnova-zgradaostecenih-potresom-na-podrucju-grada-zagreba-i-okolice/10668) (14. travnja 2021.).

6 I Europska je komisija 11. kolovoza donijela Odluku o dodjeli predujma Hrvatskoj iz Fonda solidarnosti EU-a, namijenjenog za financiranje obnove i isplatila ga u iznosu 88,9 milijuna eura bespovratnih sredstava. Taj je novac isplaćen i prije donošenja Odluke o dobivanju pomoći iz Fonda solidarnosti, a prijedlog je EK da se Hrvatskoj dodijeli ukupno 683,7 milijuna eura iz Fonda solidarnosti (https://mgipu.gov.hr/) (24. travnja 2021.).

${ }^{7}$ Prosječna starost stanovnika upravo je najveća u zagrebačkom Donjem gradu i iznosi 47,2 godine, dok je prosječna starost na razini Hrvatske 43,6 godina (DZS, 2019.), što ukazuje na ostarjelost stanovnika jezgre. 
Čitav proces zagrebačke postpotresne obnove može se promatrati i u odnosu na komparativne primjere zemalja koje su već prošle takvu obnovu i na osnovi toga vidjeti koji su modeli danas aktualni i koliko su primjenjivi u zagrebačkom slučaju. U literaturi je tako poznat proces koji se naziva "planiranje postpotresne sanacije i obnove" (engl. Postearthquake Recovery and Reconstruction Planning - PERR), koji je usmjeren na mnoge dimenzije obnove, među kojima je izgradnja stambenih objekata najvažniji dio i planski prioritet (Johnson, 2007.; Wu i Lindell, 2004.). Poboljšanje u postpotresnoj gradnji i obnovi zgrada ključni je korak u porastu otpornosti i samog susjedstva ili zajednice (engl. community resilience) koja je ugrožena. Stoga se kao temeljno ističe načelo „ljudi su na prvom mjestu“ (engl. people first) (Yang, Gao i Li, 2017.:1847) te se upozorava na nezaobilaznost uloge građana u procesu obnove jer će o tome na kraju ovisiti i njihovo zadovoljstvo. Više građanske uključenosti na lokalnoj razini može stvoriti otpornije zajednice (engl. resilient communities) u kojima su građani pozvani da sudjeluju u obnovi nakon određene katastrofe kako bi došlo do uspješnog procesa participacije (Pearce, 2003.). Ako ne postoji uspješan proces uključivanja građana, i krajnji rezultat postpotresne obnove može imati slabu učinkovitost. I u zagrebačkom slučaju, kako će se pokazati u rezultatima istraživanja, građane će se slabo uključivati i nedovoljno pozivati na suradnju. Kada građani nisu pozvani u proces upravljanja katastrofom, često se osporavaju odluke i aktivnosti onih koje te odluke donose (Pearce, 2003.:217).

Jedan od primjera samoorganiziranja građana Zagreba u različite aktivnosti vezane uz potres je i osnivanje brojnih grupa na društvenim mrežama, ponajviše na Facebooku, kako bi stanari međusobno bili brže i točnije informirani oko sanacijskog procesa, a ujedno i jedni drugima podrška u toj teškoj situaciji. Kad se niti godinu dana nakon potresa situacija nije značajno promijenila jer se proces sanacije i obnove činio izrazito sporim, građani iz središta grada, iz nekoliko grupa na društvenim mrežama, povezali su se i osnovali udrugu građana simptomatičnog naziva $S S^{8}$ kako bi izvršili pritisak na vladajuće institucije i poručili da je krajnje vrijeme da obnova krene intenzivnijim tempom i da se građane uključi u taj proces. ${ }^{9}$ Građani su vrlo brzo shvatili da je upitno u kojem će vremenu biti obnovljeni njihovi stanovi i zgrade te da obnova treba biti planski vođena kako bi se izbjegli prijašnji rizici te fizička i društvena ranjivost (Lindell, 2013.). Važan faktor u tom procesu upravo je postojanje povjerenja između institucija i građana kako bi se navedeni rizici izbjegli.

\footnotetext{
8 Izvor: https://soszagreb.org/ (30. travnja 2021.)

9 I u Italiji nakon potresa 2009. godine stanovnici L’Aquile pokazali su određeno nezadovoljstvo odlukama donesenima na razini njihove vlade. Sami su izradili ekoselo nakon što su odbili stambeno rješenje koje je ponudila talijanska vlada. Zajednica je razvila autonoman stambeni projekt prema svojim potrebama, koji je podržavao njihov identitet i bio u suprotnosti s vladinim planom, koji se doživljavao s velikom skepsom (Fois i Forino, 2014.).
} 


\section{Metodološki okvir istraživanja}

Istraživanje je provedeno kvalitativnom metodologijom na uzorku od 27 sugovornika, suvlasnika nekretnina u Donjem gradu iz 22 ulice. Provedeni su polustrukturirani intervjui tehnikom prikupljanja podataka licem u lice. Kriterij za uključivanje sugovornika u uzorak bilo je vlasništvo nad nekretninom te oštećenost nekretnina u kojima stanuju (u manjoj ili većoj mjeri). Poduzorak su činili predstavnici suvlasnika ${ }^{10}$ (13), odnosno vlasnici nekretnina koji stanare predstavljaju kod upraviteljskih tvrtki koje upravljaju financijskom imovinom zgrada, za koje je pretpostavljeno da će imati više informacija o oštećenjima zgrada i stanova te različitim aspektima obnove. Prosječna starost sugovornika bila je 52 godine, a po spolu zastupljeno je bilo 12 muškaraca i 15 žena. Prema obrazovnom statusu 15 sugovornika bilo je visokoobrazovano, a 12 ih je imalo srednjoškolsko obrazovanje. Većina sugovornika bila je zaposlena, dok je pet sugovornika bilo u mirovini. Istraživanje je provedeno u 22 ulice Donjeg grada. Sve obuhvaćene zgrade u uzorku sagrađene su krajem 19. stoljeća odnosno do 1960-ih godina. Svi su sugovornici dobrovoljno pristali na intervju te im je bila zajamčena anonimnost.

Uzorak je prikupljen metodom snježne grude (engl. snowball method) (Johnson, 2014.; Noy, 2013.) jer, između ostaloga, većinski upravitelj nekretnina u Zagrebu na naš službeni upit nije mogao do vremena početka istraživanja dostaviti podatke o predstavnicima suvlasnika. Situacija epidemije otežala je provođenje intervjua, pa su oni provedeni u dvije faze: prva u jesen 2020. i druga početkom 2021. godine, nakon tzv. petrinjskog potresa. Intervjue su provele autorice istraživanja, transkribirani su, a potom analizirani u NVivo 12 tematskom analizom (Boyatzis, 1998.). Intervjui su trajali 30 - 60 minuta. Kodiranje je prvenstveno bilo deduktivnog karaktera; temeljem teorijskih saznanja konstruirana su istraživačka pitanja te identificirani kodovi i teme. Pojedini kodovi i teme proizašli su iz induktivne analize, nakon čega se pristupilo kritičkoj interpretaciji (Terry i sur., 2017.).

Protokol za intervjue bio je podijeljen na dva osnovna dijela: a) oštećenja nastala u potresu na zgradi i stanu te b) viđenje dugoročne obnove u kontekstu urbane obnove središta grada. Po navedenim dijelovima protokola sugovornici su iznosili stavove o različitim pitanjima: prvo o obnovi od potresa i različitim pitanjima u vezi s oštećenjem zgrade i stana (npr. opis i vrsta oštećenja, način sanacije, financiranje sanacije, prodaja dijelova zgrade, međuljudski odnosi, povjerenje u institucije, mišljenje o institucionalnoj pomoći i sl.), a zatim o postpotresnoj obnovi gradskog središta u dugoročnom smislu (npr. protupotresna obnova zgrada i javnih institucija, iseljavanje iz centra grada, apartmanizacija, izgled središta grada, promet, zelenilo, obnovljivi izvori energije). Stoga su glavna istraživačka pitanja bila: 1 . S kojim su se vrstama oštećenja zgrada i stanova

\footnotetext{
10 Međuvlasničkim ugovorom suvlasnici određuju uvjete i način upravljanja zgradom, pobliže podatke o osobi koja će upravljati zgradom, opseg poslova koje će takva osoba obavljati i odgovornost za njihovo izvođenje. Predstavnik je suvlasnika osoba koja, jednostavno objašnjeno, predstavlja vezu između upravitelja i suvlasnika zgrade. (https://www.gskg.hr/default.aspx?id=170).
} 
sugovornici susreli?; 2. Kakva su iskustva sugovornika s različitim akterima po pitanju sanacije zgrada i stanova (predstavnici suvlasnika, upravitelji zgrada)? i 3. Kako stanari vide mogućnosti obnove središta grada? Na osnovi dobivenih podataka u ovom radu izdvojeni su i analizirani rezultati pet tematskih cjelina: oštećenja stanova $i$ zgrada, financiranje sanacije na oštećenim zgradama, problemi na nekoliko razina u provedbi procesa obnove, procesi iseljavanja iz središta $i$ apartmanizacija te cjelovita obnova gradskog središta.

\section{Rezultati}

\section{Oštećenja stanova i zgrada}

Oštećenja nakon potresa kako u stanovima tako i u zgradama u Donjem gradu različita su i obuhvaćaju manje štete (npr. oštećenja boje i žbuke) kao i veća oštećenja (zidova, krovova, dimnjaka). Štete nastale u stanovima uglavnom su sanirane relativno brzo nakon potresa kako bi što prije bili prihvatljivi za život stanara. Manjem dijelu stanara nije bio moguć povratak u stanove, pa su zatražili alternativni smještaj. Na zgradama su nakon prvotnih, brzih i preliminarnih procjena statičara postavljene oznake oštećenja (crvena, žuta i zelena ${ }^{11}$ s pripadajućim potkategorijama), no u nekim slučajevima kasnije su mijenjane na zahtjev stanara koji su tražili detaljnije procjene statičara.

Ja sam u Medulićevoj. To je četverokatnica... Zgrada je dobila žutu i zelenu naljepnicu u isto vrijeme zbog toga što se zabatni zid srušio, oštećeni su dimnjaci. Zvali smo još jednom statičare, mi osobno, privatno $i$ onda su još jednom pregledali $i$ rekli da je takva situacija. Zgrada je iz 1933. (stanarka 8)

No, sugovornici dalje ističu da su se žuta ili čak zelena oznaka dobivale i u onim slučajevima kada je zgrada bila mnogo više oštećena ili nesigurna za život te je zapravo trebala dobiti crvenu oznaku, što je posebno važno napomenuti jer ukazuje na brz i ne uvijek dovoljno pouzdan način procjene šteta. Što se tiče klasifikacije oštećenja s obzirom na godinu izgradnje, starije su zgrade (izgrađene dvadesetih i tridesetih godina 20. st.) uglavnom pretrpjele veća oštećenja od novijih, te su, ovisno o kvaliteti gradnje, na istoj lokaciji različito podnijele potres.

Zgrada je dobila zelenu oznaku i to nije mijenjano i još uvijek nema plin (uz ostale, veće štete, krov, dimnjake $i$ sl.). Navodno su našli majstore koji će drugi tjedan raditi dimnjake $i$ kad sve bude gotovo će pustiti plin u zgradu. Dakle zgrada je za grijanje neupotrebljiva, makar ljudi žive tamo. (stanar 14)

11 Prema informacijama Hrvatskog centra za potresno inženjerstvo cilj je brzog pregleda zgrada utvrđivanje stupnja oštećenja zgrada u odnosu na zaštitu života i imovine, odnosno određivanje je li zgrada uporabljiva, neuporabljiva ili privremeno neuporabljiva (https://www.hcpi.hr/upute-za-gradane) (27. travnja 2021.) 
Stan je poprilično oštećen s obzirom da je na četurtom katu pa zahtijeva veće popravke a i s obzirom na to da je zgrada iz 1926-e. Zidana je konstrukcija, ima drvene grede, i taj dio zgrade je nadogradivan 1960-ih... dogodili su se nekakvi pomaci u konstrukciji, odnosno u stropu. (stanar 1)

Sugovornici koji imaju stanove na višim katovima zbog oštećenja i urušavanja krovova i dimnjaka pretrpjeli su veća oštećenja u stanovima (prokišnjavanja, uništenja žbuke, pomicanja zidova itd.) od onih na nižim katovima. Pojedini sugovornici morali su odseliti iz svojih domova na određeni period.

Stan treba velike popravke, puno je toga za popravak, ima pukotina i bilo je curenja. Vratila sam se u stan nakon što sam dio vremena boravila kod prijateljice i oca. Jako mi je teško bilo organizirati život u tom periodu, i sada isto, jer se stvari nisu baš puno pomakle. (stanarka 6)

Stan treba veće popravke. Ja sam ispod krova, pa mi je prostor zbog toga u gorem stanju nego ostalima u zgradi. Nakon drugog potresa je opet došlo do oštećenja na krovu, bilo je curenja, pa smo imali problema i s tim. (stanarka 7)

U pojedinim su slučajevima stanari čekali ili još uvijek čekaju obnovu same zgrade kako bi naknadno obnovili svoje stanove, budući da je obnova njihovih zgrada bila usko povezana s obnovom stanova.

Još uvijek radimo na stanu. U našem slučaju nije imalo smisla ići s obnovom jer u sobi je curio krov, sve je bilo prepuno vode, digla se žbuka, neće se moći samo ofarbati nego se mora napraviti sanacija, $i$ sve dosad je bilo besmisleno dok se zgrada ne sanira. Zgrada je izgradena krajem 20-ih godina prošlog stoljeća. (stanarka 11)

Slika 3.

Primjer oštećenja zgrada u središtu

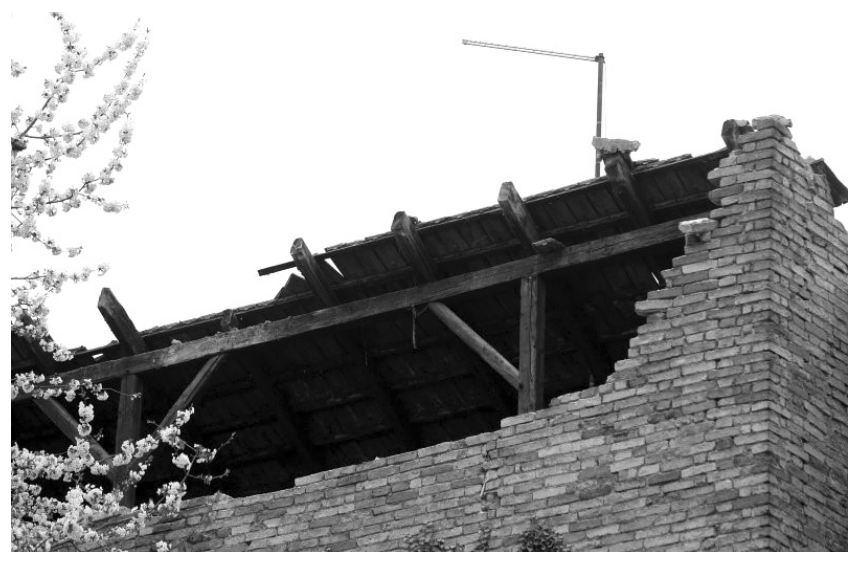

Izvor: https://tinyurl.com/n89zkt97 (2. svibnja 2021.) 


\section{Financiranje sanacije na oštećenim zgradama}

Većina sugovornika nije dobila nikakvu naknadu od grada ili države bilo u vidu financijske pomoći, građevinskog materijala ili subvencioniranja troškova, te stoga ni ne pokazuje povjerenje u ovlaštene institucije. Oni pokazuju skoro jednako nepovjerenje prema institucijama Grada Zagreba i državnim institucijama, dok nešto bolje stoji povjerenje stanara prema pomoći Europske unije.

Ne znamo gdje su novci, kako se uopće dode do tih sredstava, gdje su donacije, gdje je novac od EU, mi to nista ne znamo. Znamo da ćemo dobiti pourat sredstava za ovo za što smo podizali kredit. Za statičku obnovu koja košta ogromnu lovu mi nemamo para, a čini mi se da ćemo ispasti iz te mogućnosti baš zato jer ne možemo ulaziti u statičku obnovu... Nemam povjerenja ni u jednu instituciju. (stanar 6)

Ja imam povjerenje u EU. Taj fond za obnovu, to su vanjska sredstva. Da li će davati grad onaj dio koji mora, valjda hoce kad je tako dogovoreno, da ce ih EU natjerati. (predstavnica stanara 11)

Kod pitanja o tome na čija će se sredstva i izvore financiranja osloniti u procesu obnove, stanari najčešće smatraju da će se prvenstveno trebati osloniti na vlastita ulaganja i sredstva zajedničke pričuve, koja je u mnogim zgradama nakon potresa uvećana zbog kreditnih opterećenja. Jedna od sugovornica ističe kako su u njenoj zgradi do sada bila uplaćivana minimalna sredstva u zajedničku pričuvu, po svemu nedostatna za bilo kakve značajnije popravke nastale oštećenjima ili su pak česti slučajevi neredovitih platiša zajedničke pričuve, koji sada koče proces podizanja kredita.

Imamo još problem što u kući imamo jednu suvlasnicu koja u stvari ne znam koliko godina ne plaća pričuvu, 82 tisuće kuna je dužna za neplaćenu pričuvu. Mi sad, recimo, da bi digli kredit za adaptaciju zabatnog zida, nama banka ne daje kredit. (stanarka 8)

Nismo dobili nikakvu institucionalnu pomoć, rješavali smo sve iz vlastitih sredstava, odnosno preko kredita s GSKG-om. (stanar 3)

Mi smo bili jedna od onih zgrada koje su plaćale minimalnu pričuvu. Katastrofa, „kikiriki" neki od pričuve, 1,7 kn po kvadratu otprilike... Sad ćemo pokriti kredit za sanaciju krova i zabat. Postoje i ostali troškovi, a kad imate te radove morate imati nadzor radova, ili za projekt sanacije dimnjaka, i to ćemo platiti iz pourata za hitne intervencije. (predstavnica suvlasnika 3)

Odgovori ukazuju na nejasnu situaciju između građana i institucija, a napominju i da se pojavom dugoočekivanog Zakona o obnovi situacija nije značajno promijenila. 
Prema Zakonu, obnova se odnosi samo na zgrade i tzv. konstrukcijsko ojačavanje ${ }^{12}$, a uz nastalu kaotičnu situaciju na računima stambenih zgrada stanari nisu voljni ići u takvu cjelovitu vrstu obnove, već žele što brže riješiti primarna oštećenja tzv. nekonstrukcijskog tipa (dimnjaci, zabati, dizala i sl.), što je brojnim propisima otežano.

\section{Problemi na nekoliko razina u provedbi procesa obnove}

Uz proces obnove javljaju se mnogi problemi koji ga dodatno usporavaju, a jedan je od njih i prikupljanje opsežne dokumentacije koju propisuje Zakon o obnovi. Dok su neke zgrade u sanaciju krenule „školski“ i obavile sve potrebne predradnje da dobiju pomoć u sanaciji, pojedini suvlasnici strahuju da će biti odbijeni od Fonda zbog nepotpunosti dokumentacije ili zbog kvalitete izvođenja sanacije, čime žele naglasiti svoju nesigurnost u takav proces obnove.

Što se tiče dobivanja novaca za neke radove kao što je saniranje zabatnih zidova, natječaj traje do 1. 6. Mi još nismo aplicirali, ali imamo namjeru. Da li ćemo dobiti, ne znam. Kad smo krenuli u sanaciju nije trebala tako iscrpna dokumentacija kao što sad treba. Na primjer, nije trebao inženjerski, statičarski, gradevinarski elaborat. Sad treba, pa smo retroaktivno vadili te dokumente kako bi uopce mogli aplicirati. Mislim da nemamo svu dokumentaciju i još uvijek apliciramo. (stanar 3)

„Dokumentacija nije potpuna, žao nam je“... „Radovi nisu izvedeni na način na koji smo mi propisali - žao nam je“. „Radove nije radila osoba koju smo mi... žao nam je"... Problem je $i$ u tome sto vi s vlastitim sredstvima ne dobivate kvalitetu za svoj novac. Jer vjerojatno svi koji će biti na tržištu vrlo brzo će shvatiti da kvaliteta ne generira zaradu. (stanar 1)

Pojedini su stanari istaknuli i probleme vezane uz konzervatorsku dozvolu, koja po njima za zgrade koje ne spadaju u korpus vrijedne arhitekture nije potrebna i dodatno im komplicira obnovu. Za takve je zgrade potreban projekt obnove koji utvrđuje nadležno tijelo u skladu s propisima kojima se uređuje zaštita i očuvanje kulturnih dobara, ${ }^{13}$ što dodatno usporava proces prikupljanja dokumentacije te samu obnovu na kraju.

12

U Zakonu o obnovi, primjerice, stoji da je „pojačanje konstrukcije izvođenje radova pojačanja potresom oštećene građevinske konstrukcije zgrade kojima se postiže povećanje mehaničke otpornosti i stabilnosti zgrade u odnosu na potresno djelovanje u skladu s Tehničkim propisom“. Privatne se zgrade ne moraju cjelovito obnavljati kao što se moraju „oštećene zgrade javne namjene“ (Zakon o obnovi zgrada oštećenih potresom 2021., 3. i 9. str.).

13 Projekt obnove zgrade za cjelovitu obnovu koja je pojedinačno zaštićeno kulturno dobro ili koja se nalazi u povijesnoj urbanoj cjelini Grada Zagreba i kulturno-povijesnim cjelinama na području Sisačkomoslavačke i Karlovačke županije izrađuju ovlašteni inženjer građevinarstva koji ima najmanje pet godina radnog iskustva u projektiranju konstrukcija i ovlašteni arhitekt, od kojih barem jedan ima dopuštenje ministarstva nadležnog za kulturu za obavljanje poslova zaštite i očuvanja kulturnih dobara, te ovlašteni inženjer strojarstva i ovlašteni inženjer elektrotehnike, ako za to postoji potreba. (Zakon o obnovi zgrada oštećenih potresom 2021., 10. str.) 
Pitanje je da li ćemo dobiti pourat novca, da li će tu doći do daljnjih maltretiranja od strane institucija, konzervatorskog zavoda, koji radi probleme gdje treba i ne treba. ...tipa na zgradi poput naše koja nije zaštićena, ali je u zaštićenoj zoni, primjenjuju se ista pravila kao i na kulturni spomenik. Nema veze što je zgrada iz 1938., bezlična je, nije spomenik kulture. Ako hoćeš nešto raditi, napravit će isti problem kao i za zgradu koja ima neku umjetničku vrijednost, odnosno baštinsku. Očekujem i probleme od plinare i od dimnjačara. (predstavnik suvlasnika 7)

O mogućnostima i dinamici procesa sanacije ovisili su i međuljudski odnosi u zgradi. Ako je proces dogovora među stanarima rješavan na zadovoljavajući način, i odnosi su se ocjenjivali zadovoljavajućima ili čak boljima nego ranije. Ako se pak radilo o nezadovoljavajućim dogovorima ili nepostizanju dogovora oko nužnog povećanja zajedničke pričuve, sugovornici su smatrali da su se odnosi u zgradi pogoršali i često su usporavali daljnju obnovu jer je često i zajedničko vlasništvo na razini zgrade bilo različito shvaćeno.

Meni se čini da su se mecu tzv. normalnim stanarima, onima koji plaćaju sve, kojima je stalo da kuća funkcionira, odnosi čak poboljšali. Da smo postali povezaniji, imamo svoju grupu na Whatsappu, sve se dogovaramo i čak su se u prvo vrijeme nakon potresa ljudi śalili, sad je opet nekakva normala, ali bolje smo se povezali i čini mi se da je to $O K$. (stanarka 8)

Ono što sam primijetio [kod stanara] je nerazumijevanje zajedničkog dobra. Bilo kakva javna dobra, trgovi, ulice, grad... to tek ne razumiju. Ako ne razumiješ da je dimnjak od zgrade, podrum od zgrade, krov od zgrade ili kanalizacija, onda ne razumijes ništa. (predstavnik suvlasnika7)

Jedan je od važnih elemenata (ne)zadovoljstva u procesu obnove i rad predstavnika suvlasnika. Zadovoljstvo radom predstavnika suvlasnika sugovornici su ocijenili vrlo različito, budući da su njihove aktivnosti sezale od potpunog neangažmana i inertnosti, napuštanja posla predstavnika suvlasnika, prebacivanja posla na druge stanare, samoorganiziranja stanara oko procesa obnove uslijed nedovoljnog angažmana predstavnika pa do brzog i efikasnog rješavanja problema sanacije (jasne komunikacije i dogovora sa stanarima te izvođačima radova). Može se reći da su iskustva različita, ali da su se i očekivanja od predstavnika suvlasnika u ovoj situaciji uvećala. Sugovornici su svjesni i da je angažman predstavnika suvlasnika bio neposredno vezan uz rad upravitelja zgrade.

Predstavnica suvlasnika je u početku bila vrlo organizirana i pokazalo se da će ona sve jako promptno i precizno rijesiti, medutim, bilo je sve gore i ona je kasnije bila jako neorganizirana. Tako da bih joj u početku dao dosta visoku ocjenu, a sad jako slabu. No, nitko iz GSKG nije izaśao na teren, dao savjet, pomogao s papirima, samo je došao statičar. (stanar 12) 
Zadovoljstvo radom upravitelja zgrade jedan je od najvažnijih elemenata procesa obnove $s$ obzirom na to da upravitelj ima nadzor nad financijama zgrade, omogućava kreditno zaduživanje te pomaže suvlasnicima u traženju ponuda za izvođenje radova. Upravitelj zgrada u ovome istraživanju u većini slučajeva bio je GSKG (Gradsko stambeno-komunalno gospodarstvo), koji je ujedno i najveći upravitelj zgradama u Zagrebu. Samo je nekolicina stanara izjavila da su za upravitelja odabrali neku drugu, privatnu tvrtku. U kontekstu upravljanja financijama zgrade sugovornici su spomenuli različite probleme: od manjka zainteresiranosti i nedostupnih referenata, potkapacitiranosti stručne službe, odugovlačenja procesa sanacije zgrada pa do problema s izvođačima radova koji se nalaze na popisu onih s kojima GSKG surađuje, a čije su cijene znatno više od onih koje se mogu dobiti od izvođača koji nisu na popisu GSKG-a.

Mislim da su totalno potkapacitirani. Mi s njima imamo dosta dobre odnose jer smo ranije već počeli sanirati, s njima smo već prije radili. Referent naš je uredan, ali ne previše koristan... Oni imaju toliko posla sada da ne stižu nešto ozbiljnije. Ne mogu oni to, njih je premalo. Dizali smo dva kredita preko njih kod ZABE $i$ to je sve išlo. (predstavnica suvlasnika 11)

Zadovoljna sam što su se uvijek javljali na telefon, rješavali dio stvari vrlo korektno, ali su zavlačili provedbu koraka u rješavanju (dizanje kredita, upute oko izvodenja, predlagali projektante koji su davali ponude za nepotrebne projekte npr. glavni projekt za sanaciju dimnjaka u iznosu cca 50.000 kuna...), i kredit i projekte i izvođače smo morali sami organizirati, dokumentaciju koja je gotova još nisu predali za subvenciju. (predstavnica suvlasnika 2)

Kad su vam oni upravitelji, vi morate koristiti majstora, odnosno uzimati uslugu od majstora koji je na njihovu spisku. (stanar 1)

\section{Procesi iseljavanja iz središta i apartmanizacija}

U ovoj cjelini prikazuju se procesi iseljavanja iz središta grada i mišljenje o apartmanizaciji grada, koja se dodatno intenzivirala otkako je Hrvatska ušla u EU, a Zagreb kao glavni grad razvio turističke potencijale. Oba su procesa međusobno povezana jer su mnogi stanari centra grada prodavali stanove onima koji su se počeli baviti turizmom ili su sami svoje stanove pretvarali u apartmane radi dodatnog prihoda.

Jedan dio stanara rješenje situacije u kojoj se nalaze vidi u prodaji stanova. Veliku ulogu u odluci o prodaji ima posjedovanje ušteđevine za kupnju druge nekretnine, koju mnogi nemaju. Zbog stanja stambenog fonda nakon potresa dogodio se i pad cijena nekretnina (neke procjene govore da je riječ o $20 \%$ ), koje su do sada, zbog pozicije u centru, držale vrlo visoku cijenu, čemu je pridonio i proces apartmanizacije. Međutim, najvećem broju stanara jedina je opcija obnova zgrada i stanova ukoliko ne žele da im stanovi dodatno ne izgube na vrijednosti. 
Razmišljali smo možda o tome da prodamo stan i kupimo stan u novijoj zgradi. Ne nužno da moramo seliti izvan sredista grada, ali da odemo u novu zgradu koja se izgradila kvalitetno. Međutim, odustali smo sobzirom da nemamo nekakvu ustedevinu, a situacija je takva da se jako puno stanova prodaje u centru i da je cijena kvadrata pala. (stanarka 8)

Niti je vrijeme za prodaju stana niti imamo neku drugu lokaciju. Ako me pitate za moje želje, da, ja bih se iselio, ali realne mogućnosti, kad malo racionalnije promislim, onda ne. Nisu to ni nekakve opasnosti, mislim opasnosti jesu, ali ne baš nešto s čim ne mogu živjeti. (predstavnik suvlasnika 8)

Potrebno je naglasiti i da su već spomenuti problemi oko sanacije, uz ostalo, pridonijeli pojavi nerealnog rasta cijena građevinskih radova i nekvalitetnih izvođača radova te pojavi otkupa značajnije oštećenih zgrada i stanova po znatno nižoj cijeni od one prije potresa.

Ja, konkretno, nisam imala takve ponude, ali sam čula da ljudima nude po 800 eura za metar kvadratni, to ne možeš ni u Sesvetama dobiti, a sve zbog potresa. Onda imate ljude koji drže i dalje svoju cijenu stana i neće je spustiti i u redu, njima se ne žuri, oni imaju pravo. Svatko ima pravo staviti cijenu koju hoće, ali mislim da će sljedeće godine biti još gore. (stanarka 13)

Jedan dio stanara ne želi napustiti stanove zbog navike života u centru grada, stila života koji život u centru grada nosi te osjećaja vezanosti uz mjesto stanovanja i življenja. Visoko vrednuju, primjerice, dostupnost javnog prometa te pristupačnost i blizinu mnogobrojnih sadržaja.

Ako ne bude ljudi u centru grad će biti prazan... Ja osobno volim centar, tu sam odrastao... tu mi je sve na 5 minuta. Ne bi mogao živjeti u Novom Zagrebu pa putovati. (stanar 12)

Kod pitanja o tome bi li mjere usmjerene prema zaustavljanju iseljavanja pomogle tome da stanovnici nadalje ostanu živjeti u centru grada, mnogi su sugovornici skeptični, iako se pojedini slažu kako bi mjere trebale postojati, pogotovo ukoliko bi bile usmjerene na poboljšanje kvalitete života.

Kakve mjere bi to trebale biti? Što dati ljudima da ne isele? Kako bi se nekoga moglo zaustaviti da iseli? Još kad mu ja dođem i kažem, slušaj, ja ti mogu za ovaj stan dati 7000 - 8000 kn mjesećno dobiti od najma turista pa ti vidi. Ja toliko dobivam za 35 kvadrata, znate onda koliko je za 80? (predstavnik suvlasnika 10) 
Ne znam na koji bi to nacin moglo biti uvedeno, ali trebalo bi se pobrinuti da se grad ne prazni na račun drugih ciljeva, turističkih, pa da se dogada situacija kao s nekim drugim gradovima u Europi koji ostaju bez stanovnika centra. (predstavnica suvlasnika 5)

No, sugovornici također upozoravaju i na to da ne bi smjelo doći do pretjerane apartmanizacije i turistifikacije grada, čime bi se prostor središta grada pretvorio u prostor ispražnjen od različitih sadržaja, što bi štetilo i kulturno-povijesnoj jezgri, ali i gradu u cjelini.

Mislim da je to isto jedan korak pretvaranju centra grada u muzej, prazan prostor, gdje će samo netko doći i otići, gdje nema ljudi. Ono što se dogada i na moru, u Splitu... gdje se jezgre prazne. (stanarka 8 )

Opasnost od pražnjenja središta Zagreba dovodi do pada standarda života, koji će se dodatno urušiti zbog novih financijskih troškova, koji će najviše pogoditi stariju populaciju iz središta, koja neće moći obnoviti svoje stanove i zgrade. Sugovornici time objašnjavaju apartmanizaciju, koja se zbog generacijske smjene sve više intenzivira, a time i depopulaciju koja se paralelno događa s demografskim starenjem i odumiranjem središta.

Uglavnom u centru postoji iseljavanje jer stari ljudi umru, a onda nasljednici nemaju od čega to održavati i zato je došlo do toliko puno apartmana u Zagrebu i jer su shvatili da dolaze turisti. (stanarka 13)

\section{Cjelovita obnova gradskog središta}

Cjelovita obnova gradskog središta kompleksna je tema jer cjelokupna revitalizacija predstavlja dugoročan i sustavan proces transformacije grada na funkcionalnoj, estetskoj, ekonomskoj, ekološkoj i socijalnoj razini. Skupom pitanja u ovoj cjelini nastojalo se obuhvatiti više aspekata procesa urbane obnove (izgradnju suvremenog naspram očuvanja postojećeg središta grada, pitanje prometa u centru grada, povećanje zelenih površina, protupotresnu gradnju, cjelokupno trajanje obnove i općeniti dojam o izgledu grada). Između transformacije grada u modernom smislu (naglasak na novogradnji, uređenju centra prvenstveno kao poslovne i turističke zone te zamjeni starijih i dotrajalih zgrada novima) te očuvanja i uređenja središta na način regeneracije njegovog prijašnjeg identiteta i izgleda sugovornici se većinom odlučuju za neku vrstu srednjeg puta, odnosno ravnoteže između starog i novoga identiteta grada.

Neke stvari se trebaju modernizirati i prilagoditi vremenu. Tu bi trebalo struku slušati, ja nisam arbitekt, ali mislim da bi svakako trebali biti otvoreni za promjene, za nešto drugačije i uklopiti jedno s drugim da se sačuva ono što je vrijednost staroga, a da se gradi i nešto drugačije, novije. (stanarka 8) 
Upozorava se da je u nekim situacijama gdje je došlo do velikih oštećenja zamjena starijih zgrada novima opravdana i poželjna, dok se pak u drugim situacijama, pogotovo kada je riječ o najužem gradskom središtu i kulturno-povijesnoj baštini, zagovara obnova, očuvanje te restauracija postojećeg izgleda zgrada i obnove pročelja. Većina sugovornika smatra kako centar grada ne bi trebao biti primarno uređen za poslovnu namjenu, već za stambenu, te da bi između ta dva tipa gradnje trebalo pronaći adekvatnu ravnotežu.

Mislim da treba prvenstveno detaljno rekonstruirati postojeću gradnju, pogotovo zgrade s velikim oštećenjima. I svakako napraviti neki omjer izmedu stambene i poslovne gradnje. (stanar 9)

Sugovornici smatraju da je nužan oprez pri rušenju zgrada te da treba dati prvenstvo obnovi u izvornom smislu, gdje je god to moguće, umjesto zamjenske gradnje zgrada sasvim novog ili drugačijeg karaktera.

Nisam da se ruši osim onih koje su nužne za rušenje. Zgrada na zelenom valu, vila Hermana Bolea propada i ubrzo će biti zgrada za rušenje. Ali ne bih je zamijenio s nečim drugim. Imate nešto lijepo što je nekad bilo lijepo i što je simbol $i$ što čini zagrebačku jezgru upravo takvom. (predstavnik suvlasnika 8)

Većina sugovornika slaže se is nužnošću poboljšanja javnog prometa, pogotovo tramvajskog, koji smatraju nedovoljno organiziranim i sporim. Dio je i za izgradnju podzemnih garaža zbog smanjenja opterećenja automobilskim prometom, a koje bi se gradile izvan strogog centra grada.

U Ljubljani imate velika parkiralista na periferiji i onda se ide u grad taksijem, autobusom, to možda nije loše. Možda bi se djelomično moglo riješiti na taj način. Nemam ništa protiv podzemnih garaža, pitanje je samo gdje se grade. Nije dobro da se to radi u centru grada jer auto dolazi tamo i opet imate gužvu. (stanar 10)

Neki sugovornici smatraju i da bi centar trebao funkcionirati isključivo kao pješačka zona ili barem većim dijelom biti rasterećen od automobilskog prometa, što bi dovelo neke alternativne javne oblike prometa u centar grada.

Naravno, ukoliko bi centar bio pješačka zona onda bi se moglo uvesti nekakve minibuseve. (stanar 14)

Možda se treba više približiti pješacima i biciklistima, da se razmišlja u tom smjeru. (predstavnik suvlasnika 8) 
Sugovornici se uglavnom slažu u tome da su zelene površine važne u dugoročnoj obnovi gradskog središta budući da je očita njihova redukcija i jer se postojeće često iskorištavaju za mješovitu ili poslovnu izgradnju.

Vidim da sijeku drveće i nema hlada, cijela Gundulićeva nema ni jedno drvo. Hebrangova ima i lijepo je. Tu je i Lenucijeva potkova, ali recimo neke ulice nemaju nijedno drvo, to je prestrašno. (stanarka 13)

Sugovornici su svjesni problema manjka zelenila te vide poželjne promjene u osmišljavanju održivijeg i ekološki prihvatljivijeg razvoja grada, pri čemu spominju i infrastrukturne promjene koje se tiču, primjerice, uvođenja novih i funkcionalnijih biciklističkih staza.

Potrebno je više zelenih površina i parkova, dapače. Ali isto bih morao dodati da su sadašnje biciklističke staze neupotrebljive i premale. (stanar 12)

Što se trajanja cjelokupne obnove tiče jedan dio sugovornika smatra kako će se raditi o duljem vremenskom razdoblju od deset ili više godina. Neki od njih spominju i vremenski period od dvadeset godina dijelom zbog nastale štete, a dijelom zbog financijskog opterećenja.

Dvadeset. S obzirom na katedralu i sve zgrade u centru. Sve ovisi kako budu povukli novce, ali mislim da grad Zagreb ne može tu nešto previše pomoći, a šteta je jako velika. Moje osobno mišljenje, ispod dvadeset godina ne bude. (predstavnica suvlasnika 12)

Međutim, većina ostalih sugovornika skeptična je oko provedbe ikakvog procesa cjelovite obnove gradskog središta kako zbog financija tako i zbog drugih poteškoća građevinske i tehničke prirode.

Ne znam kako je to moguće provesti jer konstrukcijski problemi su jako veliki, mi smo o tome malo razgovarali i vi praktički morate raditi stan po stan, etažu po etažu, neke stvari rušiti, neke ojačavati. Mislim da je to neizvedivo. Jer ljudi bi morali izaći iz stanova, užasna su financijska ulaganja, pa mislim da to nije provedivo. (stanarka 8)

Iako je protupotresna gradnja i ojačavanje zgrada poželjan smjer obnove za većinu sugovornika, oni ukazuju na određene poteškoće, prvenstveno vezane uz prevelika financijska ulaganja. Protupotresna obnova svih stambenih i poslovnih zgrada te protupotresna otpornost svih zgrada za javnu i društvenu namjenu (škole, vrtići, javne ustanove, crkve i drugo) neće, smatraju, ići jednakim tempom te će javne zgrade imati prednost, što sugovornici podržavaju, ali se boje da obnova mnogih privatnih zgrada neće uopće biti moguća zbog nedostatka financija. 
Prije će se te zgrade (za javnu namjenu) obnoviti buduci da su javni objekti, pa će financiranje sigurno biti hitnije. (stanar 2)

Uglavnom stanovi nisu sanirani, a toliko su narušeni zbog neodržavanja... ali još više me grozi to da je stradala Klaićeva bolnica, Petrova bolnica... (stanarka 13)

\section{Zaključak}

S obzirom na rezultate dobivene intervjuiranjem stanara Donjeg grada oštećenih u potresu, pokazalo se da je sanacija njihovih zgrada i stanova tekla sporije nego su očekivali. Većina se sugovornika nakon potresa odselila iz svojih domova na nekoliko mjeseci i zatim vratila nakon obavljenih radova i saniranja najvećih oštećenja. Rezultati kvalitativne analize pokazuju kako su zgrade u centru grada, i to pogotovo starije, građene krajem 19. i početkom 20. stoljeća, pretrpjele veća oštećenja. U početku su postojali problemi s kategorizacijom stupnja oštećenja nekretnina, a stanari kod kojih je proveden brzi statički pregled i ustanovljena veća šteta odselili su dok im se nisu stvorili uvjeti za život (nužni popravak krovova i zabata, popravak plinskih instalacija i puštanje plina, izgradnja novih dimnjaka itd.). U vrijeme kada je provedeno istraživanje mnogi su sugovornici još uvijek čekali obnovu zgrada, o čemu ponegdje ovisi i obnova oštećenih stanova.

Znatno informiraniji o sanacijskom procesu od stanara predstavnici su suvlasnika, koji su svjesni problema u zgradama, ali ističu i nezadovoljstvo suradnjom s upraviteljima zgrada. Najveći upravitelj nekretninama u Zagrebu nije dobro ocijenjen kod sugovornika i njegov se rad najčešće ocjenjuje nezadovoljavajućim u smislu potkapacitiranosti, usporavanja procesa obnove, izbjegavanja kontakta s predstavnicima suvlasnika i sl., što upućuje na slabo snalaženje upraviteljske tvrtke u kriznoj situaciji za grad. Pokazalo se i da visina zajedničke pričuve u mnogim zgradama nije dostatna za podmirenje visokih i iznenadnih troškova povezanih s elementarnom nepogodom, te su stanari većine zgrada nužno morali ići na povećanje pričuve jer je u zgradama u kojima je došlo do većih oštećenja ona bila preniska za kreditna zaduženja. Mnoge zgrade još uvijek nisu predale potrebnu dokumentaciju (čije se prikupljanje odvija uz poteškoće) u Fond za obnovu. Pojedini sugovornici sumnjaju da ni uz subvencije neće moći pristupiti obnovi jer u mnogim zgradama postoje nesuglasice među stanarima te nerazumijevanje pojma i značenja zajedničkog vlasništva. Stanari također ističu nezadovoljstvo radom predstavnika suvlasnika, za koje procjenjuju da se nisu snašli u ovoj kriznoj situaciji gdje su im bila potrebna organizacijska i šira znanja iz sektora građevinarstva. To je često dovelo do situacija u kojima je došlo do izražaja međusobno zajedništvo ili podjela među stanarima u rješavanju zajedničkih problema. Može se zaključiti kako su sugovornici prepoznali mnoge eksterne probleme potaknute potresom, prije svega političke, tehničke te građevinske prirode i povezane s upravljanjem zgradama, kao i interne, povezane uz zajedničko stanovanje. 
Problem s izvođačima radova još je jedan u nizu problema vezanih uz sanaciju nekretnina: nema ih dovoljno na tržištu, cijena izvođenja radova i materijala je porasla, a u kvalitetu izvođenja radova mnogi predstavnici nisu dovoljno upućeni. Sugovornici su nesigurni u odvijanje procesa obnove jer su dugo bili bez ključnih informacija od grada i države o tome hoće li moći dobiti i u kojoj visini subvencije za obnovu te na koji će se način ta obnova uopće realizirati. Po mnogima taj je proces bio prespor čak i unatoč donošenju Zakona o obnovi kao i osnivanju Fonda za obnovu. To je pridonijelo nepovjerenju prema ključnim akterima obnove (grad i država) odnosno nedostatku povjerenja u institucije koje bi obnovu trebale provesti. To se vidi i iz nepovjerenja sugovornika prema konstruktivnom ojačanju svih zgrada u centru, ne samo javnih, pri čemu bi za realizaciju obnove potonjih, po mnogima, trebalo čekati više od desetak godina.

U zagrebačkoj je postpotresnoj obnovi vidljivo narušeno povjerenje između građana i ovlaštenih institucija, koje ne odgovara postpotresnom modelu PERR-a, prema kojem su „ljudi prvi“ (engl. people first) kao ni procesu participacije, koji je gotovo izostao i u kojem građani nedovoljno sudjeluju. Tome u prilog govori i novoosnovana udruga građana iz zagrebačkog središta, koja od vladajućih traži da ih uključe u obnovu i njihove probleme počnu shvaćati ozbiljnije.

S druge strane, stanari podržavaju sustavnu revitalizaciju Donjeg grada i uvođenje protupotresnih mjera gradnje svih zgrada javne namjene kao i stambenih i poslovnih zgrada. No, prema mogućnosti realizacije tih mjera pokazuju skeptičnost $s$ obzirom na potrebna financijska sredstva i vrijeme izvedbe. Slažu se i da bi centar grada trebao ostati zona pretežno namijenjena stambenoj izgradnji, a samo dijelom poslovnoj. Važno im je novogradnju dovesti u ravnotežu sa starim izgledom središta, odnosno balansirati je s postojećim identitetom donjogradskih blokova. Pojedini su stanari skloni tome da se donesu posebne mjere koje će kroz poboljšanje kvalitete života zadržati stanovnike u centru, dok su pojedini skeptični treba li utjecati na iseljavanje, procjenjujući da bi kvaliteta života mogla biti čak i bolja u novijim zgradama izvan centra. U procesu cjelovite obnove grada trebalo bi, smatraju pojedini sugovornici, slušati stručnjake te voditi računa da najuže gradsko središte zadrži svoj simbolički i kulturno-povijesti značaj. Obnova centra trebala bi uvažiti poželjne urbano-ekološke standarde i zadržati ili povećati postojeći udio zelenih i javnih površina te podržati razvoj biciklističke infrastrukture. Podržava se i gradnja velikih garaža na rubnim dijelovima grada, kojima bi se smanjio automobilski promet, a time i poboljšao javni promet (prvenstveno tramvajski). Istraživanje upućuje na važnost sustavnih i ekološki održivih vizija za obnovu grada, oživotvorenih u politikama koje su usmjerene prema stanarima centra, a koje mogu sada većinom zapuštenu jezgru grada pretvoriti u sigurnu i privlačnu za stanovanje za sve one koji u centru žele ostati živjeti.

Uključiv i održiv model urbane obnove posebno je važan upravo u vremenu elementarnih nepogoda, koje ostavljaju dodatne traume u odnosu s prostorom i mjestom 
življenja, a ako se ne uzme u obzir mišljenje građana, uspješnost obnove može izostati. Vezanost uz mjesto življenja i osjećaj pripadnosti vlastitom lokalnom prostoru, u ovom slučaju zagrebačkom središtu, dovoljno su prisutni i može ih se iskoristiti u obnovi na pozitivan način. Ključno je odrediti smjer i strategiju te aktere obnove kako bi s jedne stane proces sanacije stanova i zgrada, a s druge cjelovita obnova središta kao dugoročan proces omogućili da Zagreb bude europski grad koji se razvija na „uključiv, siguran, otporan i održiv način" (engl. inclusive, safe, resilient and sustainable way), kako to preporučuju europski ciljevi i UN-ova Nova urbana agenda, primjerice UNov 11. cilj (https://sdgs.un.org/goals/goal11) za gradove u budućnosti.

\section{Literatura}

1. Boyatzis, R. E. (1998). Transforming Qualitative Information. Thematic Analysis and Code Development. Sage Publications.

2. Čaldarović, O. (1989). Društvena dioba prostora. Zagreb: Sociološko društvo Hrvatske.

3. Čaldarović, O. and Šarinić, J. (2008). First signs of gentrification? Urban regeneration in the transitional society: the case of Croatia. Sociologija i prostor, $46(3 / 4): 369-381$.

4. Damjanović, D. (2020). Što učiniti s Donjim gradom i središtem grada nakon potresa? https://web2020.ffzg.unizg.hr/blog/2020/03/27/sto-uciniti-s-donjimgradom-i-sredistem-zagreba-nakon-potresal. (Pregledano 15.11.2020.)

5. DZS (2019). Procjene stanovništva Republike Hrvatske u 2018. https://www.dzs.hr/ Hrv Eng/publication/2019/07-01-03 01 2019.htm. (Pregledano 10.10.2020.)

6. Fois, F. and Forino, G. (2014). The self-built ecovillage in L'Aquila, Italy: Community resilience as a grassroots response to environmental shock. Disasters, 38: 719-739.

7. Hegedüs, J. and Tosics, I. (1998). Towards New Models of Housing System Social Change and Urban Restructuring in Central Europe, in: Gyorgy E. (Ed.). Social Changes and Urban Restructuring in Central Europe. Budapest: Akademia Kiado: 137-168.

8. Hirt, A. S. (2012). 'Iron Curtains Gates, Suburbs and Privatization of Space in the Post-socialist City’. UK: A John Wiley \& Sons, Ltd., Publication.

9. Hrvatski centar za potresno inženjerstvo. https://www.hcpi.hr/rezultati-procjenaostecenja-gradevina-nakon-potresa-31. (Pregledano 6.5.2021)

10. Johnson, C. (2007). Strategic planning for post-disaster temporary housing. Disasters, 31 (4): 435-458.

11. Johnson, T. P. (2014). Snowball Sampling: Introduction. Wiley StatsRef: Statistics Reference Online. doi:10.1002/9781118445112.stat05720

12. Jukić, T.; Mrđa, A. i Perkov, K. (2020). Urbana obnova, Urbana regeneracija Donjega Grada, Gornjega Grada i Kaptola / Povijesne urbane cjeline Grada Zagreba. Zagreb: Sveučilišste u Zagrebu Arhitektonski fakultet, HKA i DAZ. 
13. Lindell, K. M. (2013). Disaster studies. Current Sociology, 61 (5-6): 797-825.

14. New Urban Agenda, United Nations. 2017. https://habitat3.org/wp-content/ uploads/NUA-English.pdf. (Pregledano 21. 11. 2020.)

15. Noy, C. (2008). Sampling Knowledge: The Hermeneutics of Snowball Sampling in Qualitative Research. International Journal of Social Research Methodology, 11 (4): 327-344. doi:10.1080/13645570701401305

16. Obnova zgrada oštećenih potresom na području Grada Zagreba, Krapinskozagorske i Zagrebačke županije. https://mgipu.gov.hr/o-ministarstvu-15/ djelokrug/graditeljstvo-98/obnova-zgrada-ostecenih-potresom-na-podrucju-grada-zagreba-i-okolice/10668. (Pregledano 15.12.2020.)

17. Pearce, L. (2003). Disaster management and community planning, and public participation: How to achieve sustainable hazard mitigation. Natural Hazards, 28 (2/3): 211-228.

18. Pegan, S. i Jukić, T. (2001). Polazišta i pristupi organizaciji provedbe obnove grada. Prostor, 9, 2 (22): 141-146.

19. Rogić, I. (1991). Periferijski puls u srcu od grada. Zamke revitalizacije. Zagreb: Sociološko društvo Hrvatske.

20. Seferagić, D. (2013). Razvoj sociologije grada i prostora u Hrvatskoj. Sociologija i prostor, 51196 (2): 281-290.

21. Svirčić Gotovac, A. (2010). Aktualni revitalizacijski i gentrifikacijski procesi na primjeru Zagreba. Sociologija i prostor, 48 (2): 197-221.

22. Svirčić Gotovac, A. i Zlatar Gamberožić, J. (2020). Obrana javnih prostora u zagrebačkim slučajevima „Čuvamo naš park“ i „Vratite magnoliju“. Sociologija i prostor, 58 (1): 5-31.

23. Šarinić, J. i Čaldarović, O. (2015). Suvremena sociologija grada. Zagreb: Naklada Jesenski i Turk i Hrvatsko sociološko društvo.

24. Terry, G.; Hayfield, N.; Clarke, V.; Braun, V. (2017). Thematic analysis, in: Stainton W. and Willig C. (Eds.). The SAGE Handbook of Qualitative Research in Psychology. SAGE Publications. London: 17-37.

25. Tosics, I. (2005). City Development in Central and Eastern Europe since 1990: The Impacts of Internal Forces, in: Hamilton, F. E.; Dimitrovska Andrews, K. and Pichler-Milanović, N. (Eds.). Transformation of Cities in Central and Eastern Europe. United Nations University Press: 44-78.

26. United Nations, Goal 11: Make cities and human settlements inclusive, safe, resilient and sustainable. https://sdgs.un.org/goals/goal11. (Pregledano 25.11.2020)

27. Zakon o obnovi zgrada oštećenih potresom 2021. Zakon o obnovi zgrada oštećenih potresom na području grada Zagreba, Krapinsko-zagorske županije, Zagrebačke županije, Sisačko-moslavačke županije i Karlovačke županije, NN 102/20, 10/21. https://tinyurl.com/y69f9wz3. (Pregledano 18.8.2021.)

28. Zlatar, J. (2013). Urbane transformacije suvremenog Zagreba. Sociološka analiza. Zagreb: Plejada i Institut za društvena istraživanja. 
29. Wu, J. Y. and Lindell, K. M. (2004.). Housing reconstruction after two major earthquakes: The 1994 Northridge earthquake in the United States and the 1999 Chi-Chi earthquake in Taiwan. Disasters, 28 (1): 63-81.

30. Yang, Y., Gao, P. and Li, H. (2017). Residents' satisfaction to post-Wenchuan earthquake recovery and reconstruction. Natural Hazards, 87: 1847-1858. 


\title{
Post-earthquake Renewal of Zagreb's Donji grad from the Perspective of Tenants
}

\author{
Anđelina Svirčić Gotovac \\ Institute for Social Research in Zagreb, Croatia \\ e-mail: svircic@idi.hr \\ Jelena Zlatar Gamberožić \\ Institute for Social Research in Zagreb, Croatia \\ e-mail: jelena@idi.hr \\ Mirjana Adamović \\ Institute for Social Research in Zagreb, Croatia \\ e-mail:mirjana@idi.hr
}

\begin{abstract}
After the earthquakes that hit Zagreb and Petrinja, the post-earthquake reconstruction and renewal of apartments and buildings became a key topic in the City of Zagreb and in the area of central Croatia. In the process of planning the post-earthquake rehabilitation and renewal, the involvement of residents is emphasized as one of the key factors of its success. Bearing that in mind, the research was conducted using the qualitative method of semi-structured interviews on a sample of apartment owners and representatives of co-owners in Zagreb's Donji grad $(\mathrm{N}=27)$. The paper presents the respondents' opinions on the type of sustained damage and difficulties they encounter regarding the efficiency of the city and state government institutions. The research further indicates the problems within the buildings, including insufficient maintenance fees and (dis)satisfaction with the representatives of co-owners and managers of the buildings. The results show that the rehabilitation of buildings is slow and the whole renovation process is not in line with the expectations of respondents. Despite subsidies and the adoption of the Reconstruction Act, tenants will have to rely significantly on their own finances, despite the co-financing opportunities. Regarding the project of the complete city centre renewal after the earthquake, residents expect careful planning that combines residential and commercial development, balances the old and the new and preserves the city identity. They also expect the renewal that contributes to sustainable living conditions in the city centre, meets the citizens' needs and raises the quality of living, avoiding the increasingly radical processes of touristification, apartmanisation and emigration from the city core.
\end{abstract}

Key words: urban renewal, post-earthquake reconstruction, city centre, interviews, Zagreb. 